\title{
COX-2 Inhibitors, a Potential Synergistic Effect with Antineoplastic Drugs in Lung Cancer
}

\author{
Wolfgang Hohenforst-Schmidt ${ }^{1}$, Kalliopi Domvriं ${ }^{2}$, Nikolaos Zogas ${ }^{3}$, Paul Zarogoulidis ${ }^{2} \bowtie$, Savvas \\ Petanidis ${ }^{4}$, Efrosini Kioseoglou ${ }^{4}$, George Zachariadis ${ }^{5}$, Stylianos Kakolyris ${ }^{6}$, Konstantinos Porpodis ${ }^{2}$, Mina \\ Gaga7, Haidong Huang8, Theodor Kontakiotis², Konstantinos Zarogoulidis² \\ 1. II Medical Clinic, Hospital Coburg, University of Wurzburg, Coburg, Germany; \\ 2. Pulmonary Department-Oncology Unit, "G. Papanikolaou” General Hospital, Aristotle University of Thessaloniki, Thessaloniki, Greece; \\ 3. Gene and Cell Therapy Center, Hematology Department-Bone Marrow Transplantation Unit, "G. Papanikolaou" General Hospital, Thessaloniki, Greece; \\ 4. Department of Chemical Engineering, Aristotle University of Thessaloniki, Thessaloniki 54124, Greece; \\ 5. Laboratory of Biochemistry, School of Chemistry, Aristotle University of Thessaloniki, Thessaloniki, Greece; \\ 6. Oncology Department, University General Hospital of Alexandroupolis, Democritus University of Thrace, Alexandroupolis, Greece; \\ 7. 7th Respiratory Medicine Department and Asthma Center, Athens Chest Hospital 'Sotiria', Athens, Greece; \\ 8. Pulmonary Department of the 2nd Military University Hospital of Shanghai, Shanghai, China. \\ $\triangle$ Corresponding author: Paul Zarogoulidis, M.D, Ph. D. Pulmonary Department-Oncology Unit, “G. Papanikolaou” General Hospital, Aristotle University of \\ Thessaloniki, Thessaloniki, Greece. Fax: 00302310992424 Mobile: 00306977271974 E-mail: pzarog@hotmail.com.
}

(C) Ivyspring International Publisher. This is an open access article distributed under the terms of the Creative Commons Attribution (CC BY-NC) license (https://creativecommons.org/licenses/by-nc/4.0/). See http://ivyspring.com/terms for full terms and conditions.

Received: 2016.07.28; Accepted: 2016.09.05; Published: 2017.01.01

\begin{abstract}
Background: Lung cancer represents the leading cause of cancer-related deaths worldwide and novel therapeutic approaches targeting crucial pathways are urgently needed to improve its treatment. Inflammation plays a critical role in multistage tumor development and increased evidence has supported the involvement of cyclooxygenase- 2 expression in carcinogenesis. We investigated the potential use of COX-2 inhibitors in cancer proliferation and apoptosis.

Methods: Celecoxib, rofecoxib, etoricoxib, meloxicam, ibufrofen and indomethacin are the COX-2 inhibitors included in this study. Docetaxel and Cisplatin are the chemotherapeutic agents that we combined with COX-2 inhibitors. Lung cancer cell lines ( NCl-H1048-Small cell lung cancer, A549Non-small cell lung cancer) were purchased from ATCC LGC Standards. At indicated time-point, following $24 \mathrm{~h}$ and $48 \mathrm{~h}$ incubation, cell viability and apoptosis were measured with Annexin $\mathrm{V}$ staining by flow cytometry. Statistical analysis was performed by GraphPad Prism.

Results: In Small cell lung cancer cells, following 24h incubation, combinations of docetaxel and meloxicam, docetaxel and ibuprofen, docetaxel and indomethacin, showed increased apoptosis when compared to docetaxel alone $(p<0.0001)$. In Non-small cell lung cancer cells, the $24 \mathrm{~h}$ incubation was not enough to induce satisfactory apoptosis, but following $48 \mathrm{~h}$ incubation, docetaxel plus indomethacin showed more cytotoxicity when compared to docetaxel alone $(p<0.0001)$. In addition, the combination of cisplatin plus indomethacin was the only combination to be found with higher cytotoxicity when compared to cisplatin alone after $48 \mathrm{~h}$ treatment $(\mathrm{p}<0.0001)$.

Conclusion: Depending on the drug, the synergistic effect of COX-2 inhibitors plus chemotherapeutic agents has been demonstrated in lung cancer. Our suggestion is that COX-2 inhibitors could be used as additive and maintenance treatment in combination to antineoplastic agents in lung cancer patients.
\end{abstract}

Key words: COX-2 inhibitors, lung cancer, in vitro.

\section{Introduction}

Lung cancer is still the most common type of cancer and the leading cause of cancer-related deaths worldwide [1]. Lung cancer is subdivided into two histological groups: Small Cell Lung Cancer (SCLC) and Non-Small Cell lung Cancers (NSCLC) which accounts for almost $85 \%$ of all lung cancers [2]. Small-cell lung carcinoma has an aggressive clinical course and metastases at diagnosis and widespread 
dissemination. Although a platinum-etoposide combination combined with thoracic and prophylactic cranial irradiation has been shown to improve outcome in limited-stage SCLC (TxNxM0)) and in subgroups of extensive-stage SCLC (Tx,Nx,M1a/b) the clinical outcome for SCLC remains discouraging [3]. Similarly, NSCLC appears in the advanced stage at diagnosis in the majority of the patients with no surgical treatment option. Classical chemotherapy (platinum-doublet, taxanes, gemcitabine, pemetrexed) results in modest efficacy in NSCLC. At this point, molecular targeted drugs concerning the identification of molecular biomarkers including EGFR inhibitors, have led to personalized therapy in NSCLC, but mechanisms of resistance remain to be elucidated [4]. Furthermore, multimodal therapeutic strategy has become an important treating option for NSCLC patients, however, in several studies, two or more drug combinations were proven to have superior efficacy but at the expense of added toxicity [5] [6]. Thus, novel therapeutic approaches targeting crucial pathways are urgently needed to improve the treatment of lung cancer.

The last fifteen years, it has become clear that inflammation plays a critical role in multistage tumor development [7], and some of the molecular mechanisms involved have been elucidated [8]. Several studies have supported the involvement of cyclooxygenase-2 expression in carcinogenesis [9-13]. Indeed, increased expression of COX-2 and antiproliferative effects of COX-2 inhibitors were found in several types of cancer such as osteosarcoma [14], colorectal carcinomas [15, 16], urinary bladder cancer [17], breast cancer [18], prostate cancer [19] and lung cancer $[11,20]$. Furthermore, preclinical studies in vivo have supported the benefit of COX-2 inhibition in cancer [21-25]. In addition, selective COX-2 inhibitors such as celecoxib have been included in clinical trials in non-small-cell lung cancer patients showing promising results [26-28]. Moreover, results from another clinical trial in adenoma cancer patients showed significant benefit effect in the celecoxib group of patients [29].

Taken together, these data have demonstrated a potential use of COX-2 inhibitors in cancer proliferation and apoptosis. In this study, we investigated the cytotoxicity of combined treatment of COX-2 inhibitors with anticancer agents on Small Cell Lung Cancer and Non-small cell lung cancer in vitro.

\section{Materials and Methods \\ Cell cultures and reagents}

The small cell lung cancer cell line [NCI-H1048 [H1048], ATCC ${ }^{\circledR}$ CRL-5853 ${ }^{\mathrm{TM}}$ ) was purchased from ATCC LGC Standards. NCI-H1048 cells were cultured in ATCC-formulated Dulbecco's Modified Eagle's Medium (DMEM):F12 Medium culture medium, supplemented with 5\% Fetal Bovine Serum (FBS) and with the following components, $0.005 \mathrm{mg} / \mathrm{ml}$ Insulin, $0.01 \mathrm{mg} / \mathrm{ml}$ Transferrin, 30nM Sodium selenite (final conc.), 10nM Hydrocortisone (final conc.), 10nM beta-estradiol (final conc.), extra $2 \mathrm{mM}$ L-glutamine (for final conc. of $4.5 \mathrm{mM}$ ), $5 \%$ fetal bovine serum (final conc.), all purchased from SIGMA. The non-small cell lung cancer cell line (A549, ATCC® CCL185 ${ }^{\mathrm{TM}}$ ) was also purchased from ATCC LGC Standards. A549 cell line was cultured in DMEM, supplemented with 5\% FBS, $1 \mathrm{mM}$ Penicillin-Streptomycin and $2 \mathrm{mM}$ L-glutamin, all purchased from SIGMA.

Lung cancer cell lines were incubated at $37^{\circ} \mathrm{C}$ in a humidified atmosphere containing $5 \% \mathrm{CO}_{2}[30]$ and cultured in Coming's tissue culture flasks (25 and 75 $\mathrm{cm}^{2}$ ) according to the manufacturer's protocol. After cultures reached confluence, by microscope observation were then subcultured. Cells were detached with trypsin (1:250) $2.5 \%$ and passaged. The indicated cell lines were seeded in $25 \mathrm{~cm}^{2}$ flasks $0.7 \times$ $10^{6}$ cells at a seeding density of $10^{6}$ cells for each cell. At confluence, at indicated time point, test compounds were added according to our protocol and after $24 \mathrm{~h}$ or $48 \mathrm{~h}$ incubation apoptosis was measured (Table 1).

Table 1: Protocol of the experiment.

Incubation of the drugs in lung cancer cell lines

1. Addition if chemotherapeutic agents alone for $2 \mathrm{~h}$

2. Addition of COX-2 inhibitors alone for $2 \mathrm{~h}$

3. Addition of combinations: COX-2 inhibitors + chemotherapeutic agents for $2 \mathrm{~h}$

4. After $24 \mathrm{~h}$ and $48 \mathrm{~h}$ incubation, apoptosis was measured

\section{Test compounds}

Celecoxib (Celebrex $\left.{ }^{\circledR} 100 \mathrm{mg}\right)$, rofecoxib (Vioxx ${ }^{\circledR}$ $25 \mathrm{mg}$ ), etoricoxib (Arcox $\left.{ }^{\circledR} 90 \mathrm{mg}\right)$, meloxicam (Movatec ${ }^{\circledR} 7.5 \mathrm{mg}$ ), ibufrofen (Brufen ${ }^{\circledR} 200 \mathrm{mg}$ ) and indomethacin (Fortathrin ${ }^{\circledR} 75 \mathrm{mg}$ ) are the COX-2 inhibitors included in this study. These compounds were tested in several concentrations $(5 \mu \mathrm{M}, 10 \mu \mathrm{M}$, $20 \mu \mathrm{M}, 40 \mu \mathrm{M}, 80 \mu \mathrm{M}, 100 \mu \mathrm{M}, 200 \mu \mathrm{M})$. Docetaxel $(10 \mathrm{mg} / \mathrm{ml}, 140 \mathrm{mg} / 5.5 \mathrm{~L})$ and Cisplatin $(1 \mathrm{mg} / \mathrm{ml}$, $90 \mathrm{mg} / 5.5 \mathrm{~L})$ at concentration of $25 \mu \mathrm{M}$ are the chemotherapeutic agents that we combined with COX-2 inhibitors.

\section{Analysis of the apoptotic cells with ANNEXIN VI PI}

Annexin V staining is used as a probe to detect cells that have expressed phosphatidylserine (PS) on 
the cell surface, an event found in apoptosis as well as other forms of cell death. Propidium iodide (PI) is used as a DNA stain for both flow cytometry, to evaluate cell viability or DNA content in cell cycle analysis 17 , and microscopy to visualize the nucleus and other DNA containing organelles. It can be used to differentiate necrotic, apoptotic and normal cells. The Annexin V kit used in this study was purchased from Immunostep (Salamanca, Spain). Data were acquired on a FACS Calibur (BD, Franklin Lakes, NJ, USA) instrument, and analyzed using the CellQuest Pro v6 software (BD) or FlowJo software vX.0.7 (Tree Star).

\section{Statistical analysis}

Data are presented as means \pm standard error of the mean (SEM). Multiple comparisons between experimental groups for one or more variables were performed using one- or two-way ANOVA, respectively, with Tukey's post-hoc test. Values of $\mathrm{p} \leq 0.05$ were considered as statistically significant. All the analyses were undertaken using PRISM version 6.01 (GraphPad software, version 6, San Diego, CA. USA).

\section{Results}

In SCLC, following $24 \mathrm{~h}$ and $48 \mathrm{~h}$ incubation, docetaxel was found more cytotoxic than cisplatin $(\mathrm{p}<0.0001)$, whereas in NSCLC only after $48 \mathrm{~h}$ incubation. The combination of docetaxel and COX-2 inhibitors reduced viability significantly in both cell lines when compared to docetaxel alone. In contrast, the combination of cisplatin and COX-2 inhibitors was not as cytotoxic when compared to cisplatin alone except in the case of co-treatment of cisplatin plus indomethacin, cisplatin plus meloxicam and cisplatin plus ibuprofen in SCLC after $24 \mathrm{~h}$ incubation $(p<0.0001)$. In addition, the cytotoxicity was positively associated with drug concentrations, especially in the case of celecoxib $(160 \mu \mathrm{M})$. Specifically, in SCLC cell line, co-treatment of docetaxel and celecoxib $(80 \mu \mathrm{M}$ $\mathrm{p}<0.0001)$ reduced viability more than docetaxel alone and more than cisplatin and celecoxib co-treatment after $24 \mathrm{~h}(40 \mu \mathrm{M} p<0.05$ and $80 \mu \mathrm{M} p<0.0001)$ and $48 \mathrm{~h}$ $(40 \mu \mathrm{M} 80 \mu \mathrm{M}$ and $160 \mu \mathrm{M} p<0.0001)$ incubation (Figure 1, Table 2). Similarly, combination of docetaxel and rofecoxib $(40 \mu \mathrm{M}, \mathrm{p}<0.001-24 \mathrm{~h}$ incubation, $\mathrm{p}<0.05-48 \mathrm{~h}$ incubation) was more cytotoxic than docetaxel alone. Furthermore, cytotoxicity was significantly increased in the docetaxel and etoricoxib combination $(80 \mu \mathrm{M}$, $\mathrm{p}<0.001)$ when compared to that of docetaxel alone (24h). Combinations (24h) of docetaxel and meloxicam $(200 \mu \mathrm{M}, \quad \mathrm{p}<0.0001)$, docetaxel and ibuprofen $(40 \mu \mathrm{M}, \quad \mathrm{p}<0.0001)$, docetaxel and indomethacin $(100 \mu \mathrm{M}, 200 \mu \mathrm{M}, \mathrm{p}<0.0001)$, showed increased apoptosis when compared to docetaxel alone. Following, $48 \mathrm{~h}$ incubation docetaxel/ meloxicam $(200 \mu \mathrm{M}, \mathrm{p}<0.01)$ and docetaxel/ibuprofen combinations $(40 \mu \mathrm{M} \quad \mathrm{p}<0.001)$, resulted in an increased number of late apoptotic cells $(p<0.001)$ when compared to docetaxel alone. After $24 \mathrm{~h}$ incubation, cisplatin/meloxicam, $(200 \mu \mathrm{M}, \mathrm{p}<0.01)$, cisplatin/ibuprofen $\quad(40 \mu \mathrm{M}, \quad \mathrm{p}<0.0001) \quad$ and cisplatin/indomethacin co-incubation $(200 \mu \mathrm{M}$, $\mathrm{p}<0.0001$ ), showed increased apoptotic levels when compared with cisplatin alone. No significant apoptosis was found on other combinations of cisplatin and COX-2 inhibitors after $48 \mathrm{~h}$ incubation in SCLC cell line. Finally, in SCLC, the concentrations of COX-2 inhibitors alone (celecoxib $80 \mu \mathrm{M}$, meloxicam $200 \mu \mathrm{M}$, indomethacin $200 \mu \mathrm{M})$ resulted in increased apoptosis when compared to untreated cells $(\mathrm{p}<0.0001$, Figure 2, Table 3).

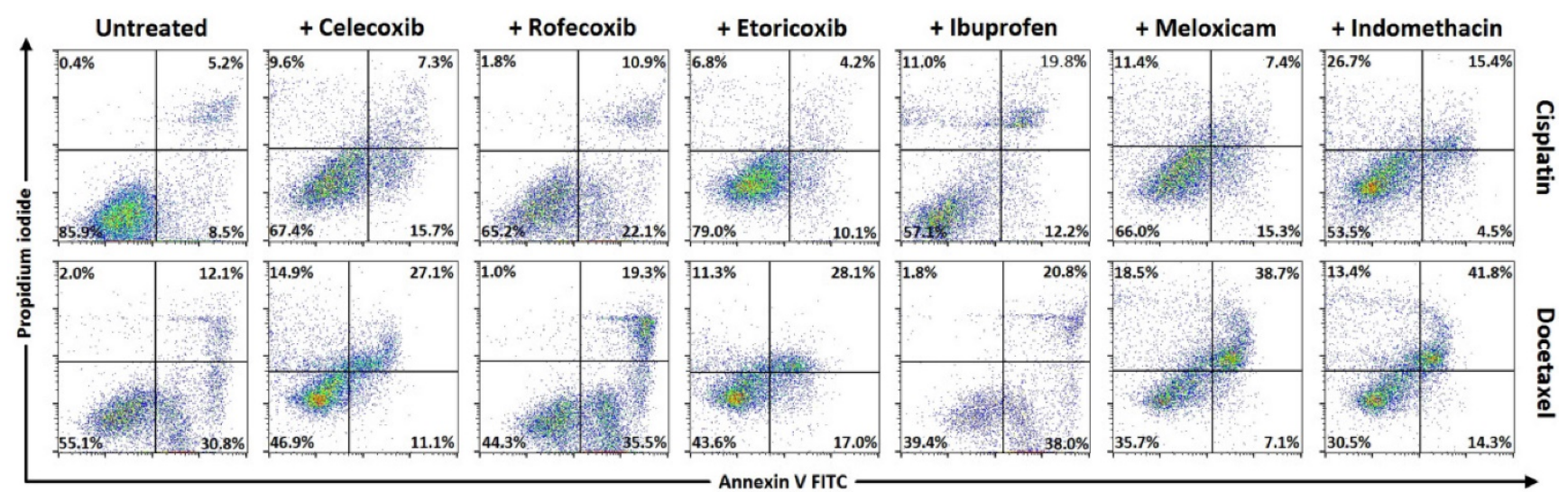

Figure 1: Cell viability and apoptosis with Annexin V/Propidium iodide by flow cytometry. Representative data for SCLC, after 24h incubation, combinations of cisplatin and docetaxel with celecoxib, rofecoxib, etoricoxib, ibuprofen, meloxicam, indomethacin. 
Table 2: Means \pm standard error of the mean (SEM) of percentages for cell viability and apoptosis with Annexin V/ Propidium iodide by flow cytometry in SCLC cell line after $24 \mathrm{~h}$ incubation with drug combinations (representative data in accordance to Figure 1).

\begin{tabular}{|c|c|c|c|c|}
\hline Drugs & Dead \% & Late Apoptotic \% & Early Apoptotic \% & Live $\%$ \\
\hline Control/ SCLC cells untreated & $2 \pm 1.5$ & $6 \pm 1.5$ & $9 \pm 1.4$ & $82 \pm 3.5$ \\
\hline Cisplatin $25 \mu \mathrm{M}$ & $3 \pm 1.3$ & $5 \pm 1$ & $13 \pm 2$ & $78 \pm 3.3$ \\
\hline Docetaxel $25 \mu \mathrm{M}$ & $5 \pm 3.6$ & $9 \pm 2.5$ & $27 \pm 1.5$ & $59 \pm 4.4$ \\
\hline Celecoxib $80 \mu \mathrm{M}$ & $9 \pm 2$ & $4 \pm 1.5$ & $14 \pm 1.5$ & $73 \pm 2$ \\
\hline Cisplatn + celecoxib $80 \mu \mathrm{M}$ & $10 \pm 3$ & $7 \pm 2$ & $16 \pm 2$ & $67 \pm 1.5$ \\
\hline Docetaxel + celecoxib $80 \mu \mathrm{M}$ & $15 \pm 2$ & $27 \pm 3.4$ & $11 \pm 2$ & $47 \pm 2.5$ \\
\hline Rofecoxib $40 \mu \mathrm{M}$ & $1 \pm 1$ & $3 \pm 1.5$ & $6 \pm 2$ & $90 \pm 2.5$ \\
\hline Cisplatin + rofecoxib $40 \mu \mathrm{M}$ & $1 \pm 0.5$ & $7 \pm 3.5$ & $14 \pm 8$ & $65 \pm 0.5$ \\
\hline Docetaxel + rofecoxib $40 \mu \mathrm{M}$ & $1 \pm 0.5$ & $20 \pm 1.4$ & $36 \pm 2$ & $44 \pm 3.2$ \\
\hline Etoricoxib $80 \mu \mathrm{M}$ & $9 \pm 1.5$ & $4 \pm 1$ & $18 \pm 2$ & $70 \pm 3$ \\
\hline Cisplatin + etoricoxib $80 \mu \mathrm{M}$ & $7 \pm 1$ & $4 \pm 1.2$ & $10 \pm 1$ & $79 \pm 2.5$ \\
\hline Docetaxel + etoricoxib $80 \mu \mathrm{M}$ & $11 \pm 2$ & $28 \pm 3$ & $17 \pm 3.5$ & $44 \pm 2$ \\
\hline Ibufrofen $40 \mu \mathrm{M}$ & $1 \pm 0.5$ & $6 \pm 1$ & $14 \pm 2$ & $79 \pm 3.4$ \\
\hline Cisplatin + ibufrofen $40 \mu \mathrm{M}$ & $9 \pm 1$ & $27 \pm 2$ & $11 \pm 1$ & $53 \pm 3.5$ \\
\hline Docetaxel + ibufrofen $40 \mu \mathrm{M}$ & $2 \pm 0.5$ & $21 \pm 2$ & $38 \pm 2$ & $39 \pm 4$ \\
\hline Meloxicam $200 \mu \mathrm{M}$ & $8 \pm 3$ & $7 \pm 2.5$ & $21 \pm 1.5$ & $63 \pm 3$ \\
\hline Cisplatin + meloxicam $200 \mu \mathrm{M}$ & $12 \pm 1.4$ & $8 \pm 1.3$ & $16 \pm 2$ & $65 \pm 3$ \\
\hline Docetaxel + meloxicam $200 \mu \mathrm{M}$ & $19 \pm 2$ & $39 \pm 1.4$ & $7 \pm 1$ & $35 \pm 3$ \\
\hline Indomethacin $200 \mu \mathrm{M}$ & $8 \pm 1.3$ & $13 \pm 2$ & $19 \pm 3.1$ & $60 \pm 2$ \\
\hline Cisplatin + indomethacin $200 \mu \mathrm{M}$ & $27 \pm 2$ & $16 \pm 2$ & $5 \pm 1$ & $53 \pm 2$ \\
\hline Docetaxel + indomethacin $200 \mu \mathrm{M}$ & $14 \pm 3$ & $42 \pm 2.3$ & $15 \pm 2$ & $30 \pm 2.5$ \\
\hline
\end{tabular}
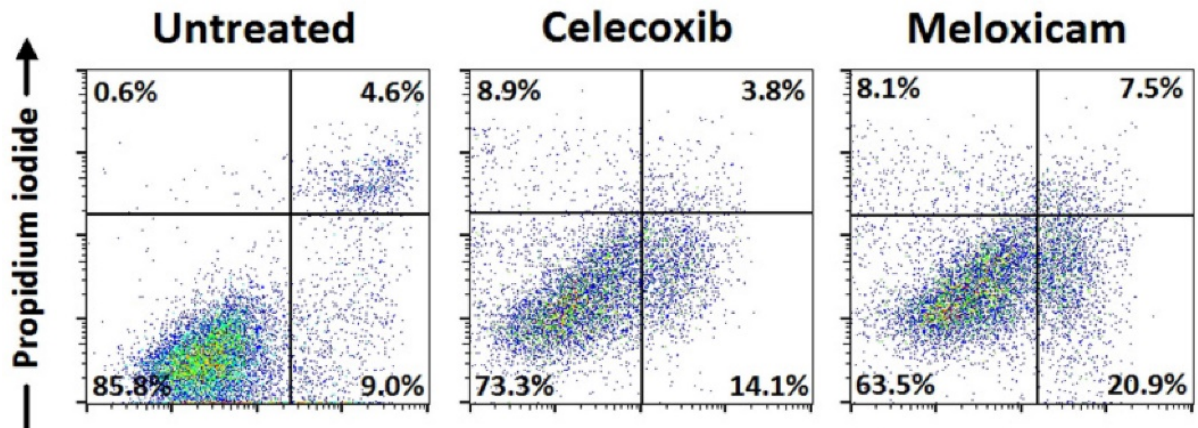

Indomethacin

Annexin V FITC

Figure 2: Cell viability and apoptosis with Annexin V/Propidium iodide by flow cytometry. Representative data for SCLC, after 24h incubation, celecoxib $(80 \mu \mathrm{M})$, meloxicam $(200 \mu \mathrm{M})$, indomethacin $(200 \mu \mathrm{M})$.

Table 3: Means \pm standard error of the mean (SEM) of percentages for cell viability and apoptosis with Annexin V/ Propidium iodide by flow cytometry in SCLC cell line after $24 \mathrm{~h}$ incubation with COX-2 inhibitors alone (representative data in accordance to Figure 2).

\begin{tabular}{|c|c|c|c|c|}
\hline Drugs & Dead \% & $\begin{array}{l}\text { Late Apoptotic } \\
\%\end{array}$ & $\begin{array}{l}\text { Early } \\
\text { Apoptotic \% }\end{array}$ & Live $\%$ \\
\hline $\begin{array}{l}\text { Untreated cells } \\
\text { SCLC }\end{array}$ & $2 \pm 1.5$ & $6 \pm 1.5$ & $9 \pm 1.4$ & $82 \pm 3.5$ \\
\hline Celecoxib $80 \mu \mathrm{M}$ & $9 \pm 2$ & $4 \pm 1.5$ & $14 \pm 1.5$ & $73 \pm 2$ \\
\hline Meloxicam 200 $\mu \mathrm{M}$ & $8 \pm 3$ & $7 \pm 2.5$ & $21 \pm 1.5$ & $63 \pm 3$ \\
\hline $\begin{array}{l}\text { Indomethacin } \\
200 \mu \mathrm{M}\end{array}$ & $8 \pm 1.3$ & $13 \pm 2$ & $19 \pm 3.1$ & $60 \pm 2$ \\
\hline
\end{tabular}

In NSCLC, the $24 \mathrm{~h}$ incubation was not enough to induce satisfactory apoptosis. Results showed increased apoptosis particularly after $48 \mathrm{~h}$ incubation of docetaxel plus indomethacin when compared to docetaxel alone $(\mathrm{p}<0.0001)$. In addition, the combination of cisplatin plus indomethacin $(p<0.0001)$ was the only combination to be found with higher cytotoxicity when compared to cisplatin alone after $48 \mathrm{~h}$ treatment (Figure 3, Table 4). Finally, in NSCLC, the concentrations of COX-2 inhibitors alone (celecoxib $80 \mu \mathrm{M}$, meloxicam $200 \mu \mathrm{M}$, indomethacin $200 \mu \mathrm{M})$ resulted in increased apoptosis when compared to untreated cells $(\mathrm{p}<0.0001$, Figure 4, Table 5). 


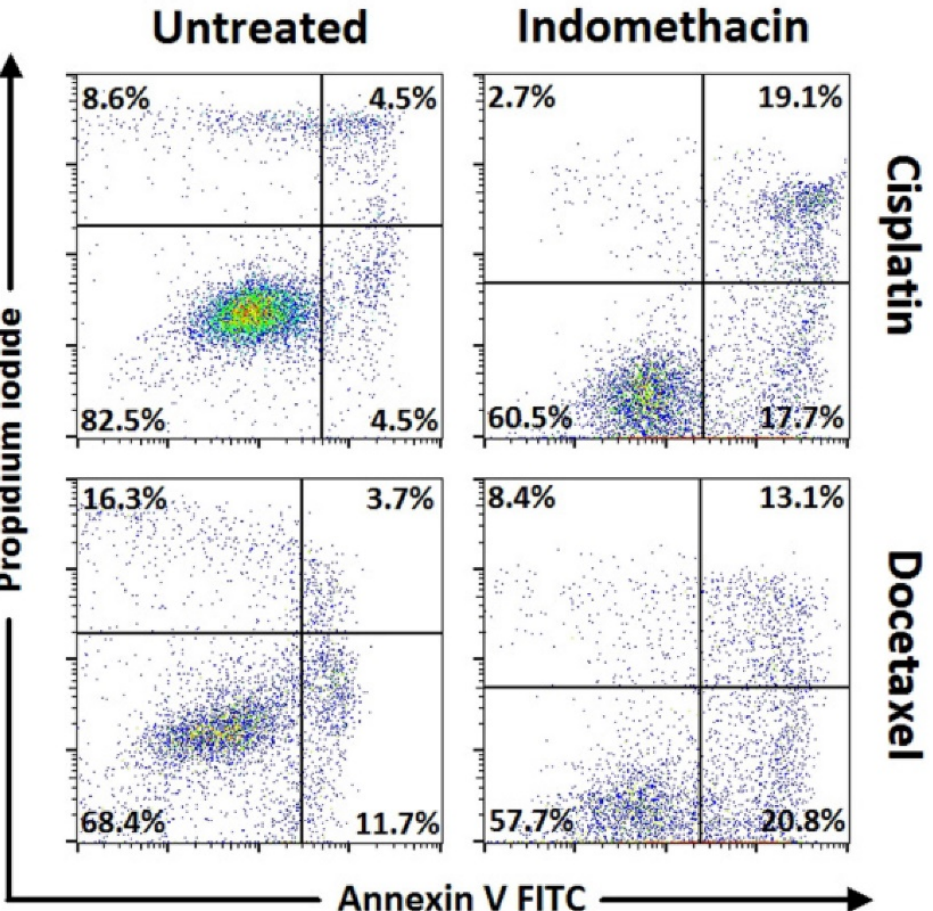

Figure 3: Cell viability and apoptosis with Annexin V/Propidium iodide by flow cytometry. Representative data for NSCLC, after 48h incubation. Combinations of cisplatin and docetaxel with indomethacin $(200 \mu \mathrm{M})$.

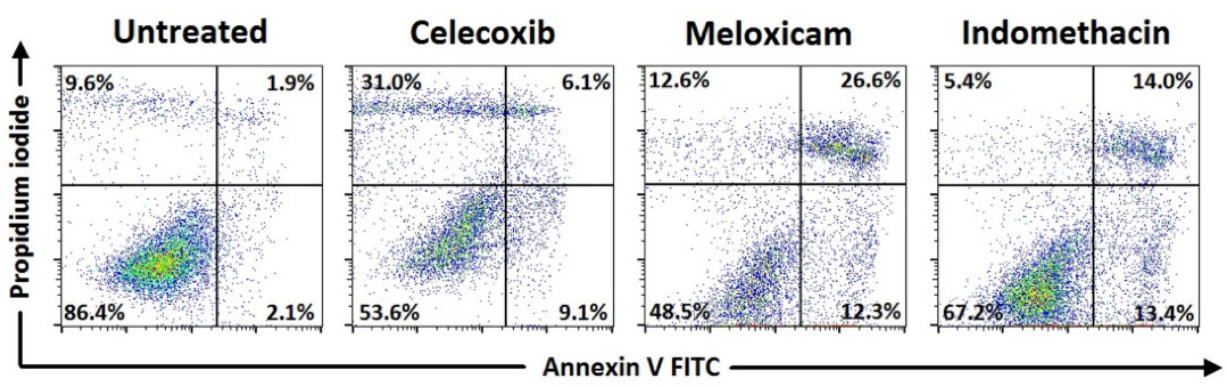

Figure 4: Cell viability and apoptosis with Annexin V/Propidium iodide by flow cytometry. Representative data for NSCLC, after 48h incubation, celecoxib $(80 \mu \mathrm{M})$, meloxicam $(200 \mu \mathrm{M})$, indomethacin $(200 \mu \mathrm{M})$.

Table 4: Means \pm standard error of the mean (SEM) of percentages for cell viability and apoptosis with Annexin V/Propidium iodide by flow cytometry in NSCLC cell line after $48 \mathrm{~h}$ incubation with drug combinations (representative data in accordance to Figure 3).

\begin{tabular}{|c|c|c|c|c|}
\hline Drugs & Dead \% & $\begin{array}{l}\text { Late } \\
\text { Apoptotic \% }\end{array}$ & $\begin{array}{l}\text { Early } \\
\text { Apoptotic \% }\end{array}$ & Live $\%$ \\
\hline $\begin{array}{l}\text { Control/NSCLC cells } \\
\text { untreated }\end{array}$ & $10 \pm 1.5$ & $2 \pm 0.5$ & $5 \pm 1.7$ & $86 \pm 3$ \\
\hline Cisplatin $25 \mu \mathrm{M}$ & $9 \pm 1.8$ & $5 \pm 0.8$ & $5 \pm 0.8$ & $82 \pm 3$ \\
\hline Docetaxel $25 \mu \mathrm{M}$ & $16 \pm 2.5$ & $4 \pm 1.6$ & $12 \pm 1$ & $68 \pm 4$ \\
\hline Indomethacin $200 \mu \mathrm{M}$ & $6 \pm 0.5$ & $14 \pm 2.3$ & $13 \pm 2.1$ & $67 \pm 3.5$ \\
\hline $\begin{array}{l}\text { Cisplatin + indomethacin } \\
200 \mu \mathrm{M}\end{array}$ & $3 \pm 0.5$ & $19 \pm 1.5$ & $18 \pm 1.6$ & $61 \pm 2.8$ \\
\hline $\begin{array}{l}\text { Docetaxel }+ \\
\text { indomethacin } 200 \mu \mathrm{M}\end{array}$ & $8 \pm 1.9$ & $13 \pm 1.4$ & $21 \pm 2$ & $58 \pm 2.3$ \\
\hline
\end{tabular}

Table 5: Means \pm standard error of the mean (SEM) of percentages for cell viability and apoptosis with Annexin V/Propidium iodide by flow cytometry in NSCLC cell line after $48 \mathrm{~h}$ incubation with COX-2 inhibitors alone (representative data in accordance to Figure 4).

\begin{tabular}{lllll}
\hline Drugs & Dead \% & $\begin{array}{l}\text { Late } \\
\text { Apoptotic } \%\end{array}$ & $\begin{array}{l}\text { Early } \\
\text { Apoptotic \% }\end{array}$ & Live \% \\
\hline Untreated cells & $10 \pm 1.5$ & $2 \pm 0.5$ & $5 \pm 1.7$ & $86 \pm 3$ \\
NSCLC & & & & \\
Celecoxib $80 \mu \mathrm{M}$ & $31 \pm 3$ & $6 \pm 1.5$ & $9 \pm 2.6$ & $54 \pm 4$ \\
Meloxicam $200 \mu \mathrm{M}$ & $13 \pm 2.9$ & $27 \pm 2.7$ & $12 \pm 1.8$ & $49 \pm 3$ \\
Indomethacin $200 \mu \mathrm{M}$ & $6 \pm 0.5$ & $14 \pm 2.3$ & $13 \pm 2.1$ & $67 \pm 3.5$ \\
\hline
\end{tabular}




\section{Discussion}

According to the National Comprehensive Cancer Network practice guidelines, the etoposide-cisplatin (EC) regimen used concurrently with radiotherapy, has been the standard chemotherapy for decades for the first-line treatment of SCLC [31, 32]. Alternative treatment strategies include taxanes (paclitaxel and docetaxel) and platinum analogues (carboplatin, cisplatin). Similarly, radiotherapy and platinum-based chemotherapy has made no progress in the treatment of NSCLC. Clinical resistance is considered another obstacle in the treatment of NSCLC [33]. Thus, the need for novel treatment combinations has widespread interest.

For more than 30 years, nonsteroidal anti-inflammatory drugs (NSAIDs) have been the focus of attention as anticancer agents to reduce the clinical signs associated with inflammation [34]. The targets of traditional NSAIDs include the cyclooxygenases 1 and 2 (COX-1 and COX-2), enzymes involved in the production of prostaglandins from arachidonic acid. It has been reported that long-term use of traditional NSAIDs is associated with serious gastrointestinal side effects that have been attributed to COX-1 inhibition [35, 36]. As a result, COX-2 inhibitors were developed that had fewer gastrointestinal side effects according to clinical studies [37-41], but had anti-inflammatory activities that were similar to those of traditional NSAIDs. In the present study, we investigated the synergistic effect of COX-2 inhibitors, with chemotherapeutic agents, docetaxel and cisplatin on the apoptosis of lung cancer cell lines. Figure 5.

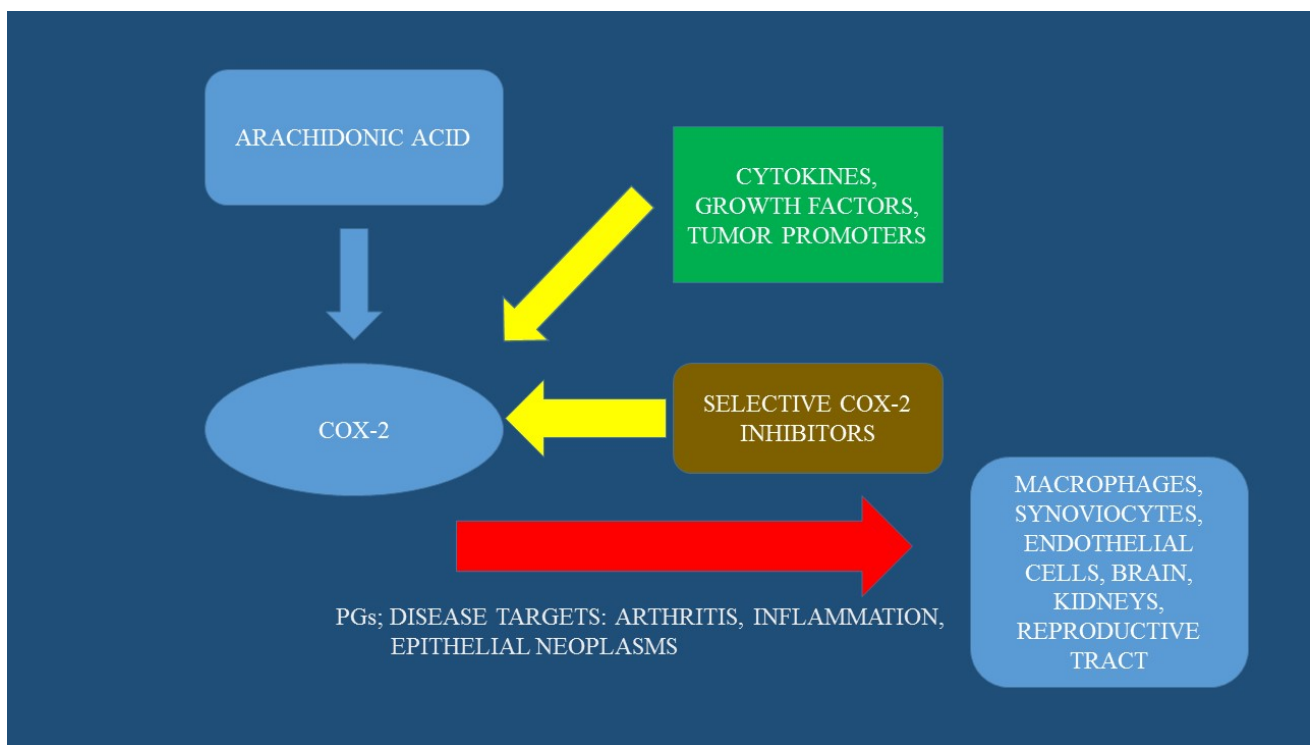

Figure 5. Mechanism of action of COX-2 inhibitors.

Traditional NSAIDs are nonselective inhibitors of both cyclooxygenase-1 (COX-1) and COX-2 which convert arachidonic acid to prostaglandin ( $\mathrm{H} 2)$. COX-2 can generally be upregulated in response to cytokines, growth factors, tumor promoters, stress and other stimuli in various tissues including lung cancer [11]. In cancer, the regulation of COX-2 is abolished, so that both enzymes are overexpressed, leading to an increase in prostaglandin (PGE2) production in these cells [42]. PGE2 via stimulation of prostaglandin E2 receptor activates multiple pathways resulting in tumor cell proliferation, angiogenesis, survival and antiapoptosis [43-46]. In lung cancer cells, particularly in adenocarcinoma, according to clinical studies, overexpression of COX-2 is considered to be a negative predictive factor in the survival of the subpopulation [47]. Similarly, in colon cancer, overexpression of both cyclooxygenases in the early adenoma stage leads to one of the first steps for its development [48]. The patients showed a significant decrease in the multiplicity of polyps and induced regression of polyps after they received sulindac, a selective COX inhibitor, for 1 year [49-51].

The appearance of increased COX-2 expression might be involved in cancer development by inhibiting apoptosis, promoting cell division, altering cell adhesion and enhancing metastasis stimulating neovascularization, antitumor immune responses and inhibition of cellular protein synthesis [52]. Since traditional NSAIDs block these activities, their inhibition of COX-2 activity could be considered for their anticancer effects. Besides, apart from these mechanisms, according to several reports, COX-2 independent mechanisms may also participate in the 
anticancer effects. Furthermore, each traditional NSAIDs such as celecoxib and rofecoxib may have their own more or less specific COX-independent target $[53,54]$. In our study, indeed each COX-2 inhibitor showed different results in lung cancer cell lines. In particular, the combinations of meloxicam, ibuprofen and indomethacin with the chemotherapeutic agents showed more significant apoptosis when compared to the other combinations in both lung cancer cell lines. Furthermore, the combination of COX-2 inhibitors with chemotherapeutic drugs showed increased apoptosis in a time-dependent manner. SCLC showed higher sensitivity to the combination than NSCLC.

The use of taxanes in cancer is based on their interference with microtubule assembly, impairment of mitosis, and changes in the cytoskeleton [55]. They also stimulate mitogen-activated protein kinases (MAPKs) and the expression of numerous genes including COX-2 [56-58]. In particular, there is growing evidence that beyond the mechanisms that control COX-2 transcription [13], post-transcriptional mechanisms are also important $[59,60]$. In our study, we observed that docetaxel had a synergistic effect with all the COX-2 inhibitors when compared with docetaxel alone in SCLC and NSCLC in vitro. It has been reported that taxanes stimulate COX-2 expression followed by increased PGE2 production, thus, resulting as expected in synergistic effect [13]. Indeed, in a phase II clinical trial on NSCLC patients, survival benefit with COX-2 inhibitor and chemotherapy was demonstrated in patients with moderate to high COX-2 expression [28]. Similarly, in our study, COX-2 inhibitors showed a synergistic effect with docetaxel on NSCLC cell line. However, in a recent phase II clinical trial the combination of docetaxel and apricoxib (COX-2 inhibitor) as second-line therapy on advanced NSCLC patients, showed negative results, implying that taxanes-driven augmentation of COX-2 expression might diminish the effect of COX-2 inhibitors [61].

$$
\text { Although, platinum-based doublet }
$$
chemotherapeutic regimens include the primary therapeutic method for lung cancer, cisplatin resistance is a main clinical problem [33]. Thus, it is urgent the need for finding combination drugs to overcome this problem. In our study cisplatin combinations with COX-2 inhibitors showed inconsistent results in both lung cancer cell lines, however the synergistic effect was obvious. Similarly, in a phase II trial the combination of celecoxib plus platinum-based chemotherapy

as first-line treatment COX-2 positive NSCLC patients, confirmed by immunohistochemical staining showed promising results [27]. Moreover, another phase II study suggested that celecoxib may safely be combined with etoposide for the treatment of extensive-stage in SCLC [62]. However, recently, Chen et al showed that celecoxib reduced an influx of cisplatin in gastric cancer in vitro, by antagonizing cisplatin-induced cytotoxicity and apoptosis in a COX-2 independent manner, suggesting the cautious selection of the combination drug with COX-2 inhibitor [63].

According to Yokouchi et al, results from several clinical trials indicate that patients that do not express COX-2 may have worse outcomes when treated with COX-2 inhibitor, perhaps due to the domination of COX-1 pathway in normal cells [64]. This study showed the importance to identify the subgroup of patients with activated COX-2 pathway. The selection of the appropriate method that will best determine the efficacy of the combination of COX-2 inhibition with chemotherapy is at need. Gitlitz et al attempted to use a patient-selection strategy in a randomized placebo-controlled study of a COX-2 inhibitor and erlotinib in NSCLC. They selected NSCLC patients based on a $50 \%$ decrease from baseline levels of a urinary metabolite of PGE2 (PGEM) in response to apricoxib, but the primary endpoint of the trial was not met, possibly due to the low cutpoint for the decline in PGEM [65]. Reckamp et al evaluated COX-2 expression in a phase II trial [66] by measuring levels of baseline PGEM based on results of their phase I trial in NSCLC $[67,68]$. They reported that COX-2 pathway represents a novel mechanism of resistance to EGFR TKI therapy in NSCLC patients. Thus, in their phase II trial, they demonstrated that erlotinib and high-dose celecoxib led to an increase in progression free survival in selected patients with wild-type EGFR and COX-2 inhibition evaluated by elevated baseline PGEM [66]. In other studies, the evaluation of COX-2 and EGFR inhibition in small sample size and unselected patients in NSCLC showed limited benefit [69-72], high lightening the need of using biomarkers and genomic data.

\section{Conclusion}

The synergistic effect of the combination of COX-2 inhibitors and chemotherapeutic agents has been demonstrated. Our suggestion is that COX-2 inhibitors could be added as maintenance treatment in lung cancer patients. However, in clinical practice several issues should be considered for further investigation. Examination of genetic and epigenetic background and exploration of biomarkers defining a subset of lung cancer patients that would benefit by these combinations combined with better understanding of COX-2 biology would shed more light on how to achieve clinical improvement. Cox-2 
inhibitors have been used with immunotherapeutic agents with effectiveness [73, 74], however; more trials are necessary for non-small cell lung cancer.

\section{Conflict of Interest}

None to declare.

\section{References}

1. Jin X, Liang N, Wang M, Meng Y, Jia B, Shi X, et al. Integrin Imaging with 99mTc-3PRGD2 SPECT/CT Shows High Specificity in the Diagnosis of Lymph Node Metastasis from Non-Small Cell Lung Cancer. Radiology. 2016: 150813. doi:10.1148/radiol.2016150813.

2. Zheng M. Classification and Pathology of Lung Cancer. Surgical oncology clinics of North America. 2016; 25: 447-68. doi:10.1016/j.soc.2016.02.003.

3. Altan M, Chiang AC. Management of Small Cell Lung Cancer: Progress and Updates. Cancer journal. 2015; 21: 425-33. doi:10.1097/PPO.0000000000000148.

4. Domvri K, Zarogoulidis P, Darwiche K, Browning RF, Li Q, Turner JF, et al. Molecular Targeted Drugs and Biomarkers in NSCLC, the Evolving Role of Individualized Therapy. Journal of Cancer. 2013; 4: 736-54. doi:10.7150/jca.7734.

5. Stinchcombe TE, Morris DE, Lee CB, Moore DT, Hayes DN, Halle JS, et al. Induction chemotherapy with carboplatin, irinotecan, and paclitaxel followed by high dose three-dimension conformal thoracic radiotherapy (74 Gy) with concurrent carboplatin, paclitaxel, and gefitinib in unresectable stage IIIA and stage IIIB non-small cell lung cancer. Journal of thoracic oncology : official publication of the International Association for the Study of Lung Cancer. 2008; 3: 250-7. doi:10.1097/JTO.0b013e3181653cf4.

6. Yoshida T, Yamada K, Azuma K, Kawahara A, Abe H, Hattori S, et al. Comparison of adverse events and efficacy between gefitinib and erlotinib in patients with non-small-cell lung cancer: a retrospective analysis. Medical oncology. 2013; 30: 349. doi:10.1007/s12032-012-0349-y.

7. Grivennikov SI, Greten FR, Karin M. Immunity, inflammation, and cancer. Cell. 2010; 140: 883-99. doi:10.1016/j.cell.2010.01.025.

8. Karin M. Nuclear factor-kappaB in cancer development and progression. Nature. 2006; 441: 431-6. doi:10.1038/nature04870.

9. Prescott SM, Fitzpatrick FA. Cyclooxygenase-2 and carcinogenesis. Biochimica et biophysica acta. 2000; 1470: M69-78.

10. Reddy BS, Rao CV, Seibert K. Evaluation of cyclooxygenase-2 inhibitor for potential chemopreventive properties in colon carcinogenesis. Cancer research. 1996; 56: 4566-9.

11. Hida T, Yatabe $Y$, Achiwa H, Muramatsu H, Kozaki K, Nakamura S, et al. Increased expression of cyclooxygenase 2 occurs frequently in human lung cancers, specifically in adenocarcinomas. Cancer research. 1998; 58: 3761-4.

12. Subbaramaiah K, Telang N, Ramonetti JT, Araki R, DeVito B, Weksler $\mathrm{BB}$, et al. Transcription of cyclooxygenase-2 is enhanced in transformed mammary epithelial cells. Cancer research. 1996; 56: 4424-9.

13. Subbaramaiah K, Dannenberg AJ. Cyclooxygenase 2: a molecular target for cancer prevention and treatment. Trends in pharmacological sciences. 2003; 24: 96-102. doi:10.1016/S0165-6147(02)00043-3.

14. Liu J, Wu J, Zhou L, Pan C, Zhou Y, Du W, et al. ZD6474, a new treatment strategy for human osteosarcoma, and its potential synergistic effect with celecoxib. Oncotarget. 2015; 6: 21341-52. doi:10.18632/oncotarget.4179.

15. Brown JR, DuBois RN. COX-2: a molecular target for colorectal cancer prevention. Journal of clinical oncology : official journal of the American Society of Clinical Oncology. 2005; 23: 2840-55. doi:10.1200/JCO.2005.09.051.

16. Eberhart CE, Coffey RJ, Radhika A, Giardiello FM, Ferrenbach S, DuBois RN. Up-regulation of cyclooxygenase 2 gene expression in human colorectal adenomas and adenocarcinomas. Gastroenterology. 1994; 107: 1183-8.

17. D'Arca D, LeNoir J, Wildemore B, Gottardo F, Bragantini E, Shupp-Byrne D, et al. Prevention of urinary bladder cancer in the FHIT knock-out mouse with Rofecoxib, a Cox-2 inhibitor. Urologic oncology. 2010; 28: 189-94. doi:10.1016/j.urolonc.2009.01.016.

18. Bocca C, Bozzo F, Bassignana A, Miglietta A. Antiproliferative effects of COX-2 inhibitor celecoxib on human breast cancer cell lines. Molecular $\begin{array}{llll}\text { and cellular } & \text { biochemistry. }\end{array}$ doi:10.1007/s11010-010-0682-4.

19. Bieniek J, Childress C, Swatski MD, Yang W. COX-2 inhibitors arrest prostate cancer cell cycle progression by down-regulation of kinetochore/centromere proteins. The Prostate. 2014; 74: 999-1011. doi:10.1002/pros.22815.

20. Takahashi $\mathrm{T}$, Kozaki $\mathrm{K}$, Yatabe $\mathrm{Y}$, Achiwa $\mathrm{H}$, Hida $\mathrm{T}$. Increased expression of COX-2 in the development of human lung cancers. Journal of environmental pathology, toxicology and oncology : official organ of the International Society for Environmental Toxicology and Cancer. 2002; 21: 177-81.

21. Oshima M, Dinchuk JE, Kargman SL, Oshima H, Hancock B, Kwong E, et al. Suppression of intestinal polyposis in Apc delta716 knockout mice by inhibition of cyclooxygenase 2 (COX-2). Cell. 1996; 87: 803-9.

22. Liu R, Zheng H, Li W, Guo Q, He S, Hirasaki $Y$, et al. Anti-tumor enhancement of Fei-Liu-Ping ointment in combination with celecoxib via cyclooxygenase-2-mediated lung metastatic inflammatory microenvironment in Lewis lung carcinoma xenograft mouse model. Journal of translational medicine. 2015; 13: 366. doi:10.1186/s12967-015-0728-1.

23. Kumar G, Patlolla JM, Madka V, Mohammed A, Li Q, Zhang Y, et al. Simultaneous targeting of 5-LOX-COX and ODC block NNK-induced lung adenoma progression to adenocarcinoma in A/J mice. American journal of cancer research. 2016; 6: 894-909.

24. Neufang G, Furstenberger G, Heidt M, Marks F, Muller-Decker K. Abnormal differentiation of epidermis in transgenic mice constitutively expressing cyclooxygenase-2 in skin. Proceedings of the National Academy of Sciences of the United States of America. 2001; 98: 7629-34. doi:10.1073/pnas.121574098.

25. Williams CS, Tsujii M, Reese J, Dey SK, DuBois RN. Host cyclooxygenase-2 modulates carcinoma growth. The Journal of clinical investigation. 2000; 105: 1589-94. doi:10.1172/JCI9621.

26. Sobolewski C, Cerella C, Dicato M, Ghibelli L, Diederich M. The role of cyclooxygenase- 2 in cell proliferation and cell death in human malignancies. International journal of cell biology. 2010; 2010: 215158. doi:10.1155/2010/215158

27. Wang Z, Duan J, Guo Q, Wei Z, Xue W, Wu M, et al. [A phase II clinical trial of celecoxib combined with platinum-based chemotherapy in the treatment of patients with advanced NSCLC as first-line treatment.]. Zhongguo fei ai za zhi = Chinese journal of lung cancer. 2008; 11: 425-30. doi:10.3779/j.issn.1009-3419.2008.03.031.

28. Edelman MJ, Watson D, Wang X, Morrison C, Kratzke RA, Jewell S, et al. Eicosanoid modulation in advanced lung cancer: cyclooxygenase-2 expression is a positive predictive factor for celecoxib + chemotherapy--Cancer and Leukemia Group B Trial 30203. Journal of clinical oncology : official journal of the American Society of Clinical Oncology. 2008; 26: 848-55. doi:10.1200/JCO.2007.13.8081.

29. Vosooghi M, Amini M. The discovery and development of cyclooxygenase-2 inhibitors as potential anticancer therapies. Expert opinion on drug discovery. 2014; 9: 255-67. doi:10.1517/17460441.2014.883377.

30. Bertram JS, Janik P. Establishment of a cloned line of Lewis Lung Carcinoma cells adapted to cell culture. Cancer letters. 1980; 11: 63-73.

31. Murray N, Turrisi AT, 3rd. A review of first-line treatment for small-cell lung cancer. Journal of thoracic oncology : official publication of the International Association for the Study of Lung Cancer. 2006; 1: 270-8.

32. Rossi A, Martelli O, Di Maio M. Treatment of patients with small-cell lung cancer: from meta-analyses to clinical practice. Cancer treatment reviews. 2013; 39: 498-506. doi:10.1016/j.ctrv.2012.09.006.

33. Galluzzi L, Senovilla L, Vitale I, Michels J, Martins I, Kepp O, et al. Molecular mechanisms of cisplatin resistance. Oncogene. 2012; 31: 1869-83. doi:10.1038/onc.2011.384.

34. Moon Y, Bottone FG, Jr., McEntee MF, Eling TE. Suppression of tumor cell invasion by cyclooxygenase inhibitors is mediated by thrombospondin-1 via the early growth response gene Egr-1. Molecular cancer therapeutics. 2005; 4: 1551-8. doi:10.1158/1535-7163.MCT-05-0213.

35. Simon LS. COX-2 inhibitors. Are they nonsteroidal anti-inflammatory drugs with a better safety profile? Gastroenterology clinics of North America. 2001; 30: 1011-25, viii.

36. Capone ML, Tacconelli S, Sciulli MG, Patrignani P. Clinical pharmacology of selective COX-2 inhibitors. International journal of immunopathology and pharmacology. 2003; 16: 49-58.

37. Alsalameh S, Burian M, Mahr G, Woodcock BG, Geisslinger G. Review article: The pharmacological properties and clinical use of valdecoxib, a new cyclo-oxygenase-2-selective inhibitor. Alimentary pharmacology \& therapeutics. 2003; 17: 489-501.

38. Riendeau D, Percival MD, Brideau C, Charleson S, Dube D, Ethier D, et al. Etoricoxib (MK-0663): preclinical profile and comparison with other agents that selectively inhibit cyclooxygenase-2. The Journal of pharmacology and experimental therapeutics. 2001; 296: 558-66.

39. Goldenberg MM. Celecoxib, a selective cyclooxygenase-2 inhibitor for the treatment of rheumatoid arthritis and osteoarthritis. Clinical therapeutics. 1999; 21: 1497-513; discussion 27-8. 
40. Silverstein FE, Faich G, Goldstein JL, Simon LS, Pincus T, Whelton A, et al. Gastrointestinal toxicity with celecoxib vs nonsteroidal anti-inflammatory drugs for osteoarthritis and rheumatoid arthritis: the CLASS study: A randomized controlled trial. Celecoxib Long-term Arthritis Safety Study. Jama. 2000; 284: 1247-55.

41. Bombardier C, Laine L, Reicin A, Shapiro D, Burgos-Vargas R, Davis B, et al. Comparison of upper gastrointestinal toxicity of rofecoxib and naproxen in patients with rheumatoid arthritis. VIGOR Study Group. The New England journal of medicine. 2000; 343: 1520-8, 2 p following 8. doi:10.1056/NEJM200011233432103.

42. Kamei D, Murakami M, Nakatani Y, Ishikawa Y, Ishii T, Kudo I. Potential role of microsomal prostaglandin $E$ synthase-1 in tumorigenesis. The Journal of biological chemistry. 2003; 278: 19396-405. doi:10.1074/jbc.M213290200.

43. Dorsam RT, Gutkind JS. G-protein-coupled receptors and cancer. Nature reviews Cancer. 2007; 7: 79-94. doi:10.1038/nrc2069.

44. Shao J, Lee SB, Guo H, Evers BM, Sheng H. Prostaglandin E2 stimulates the growth of colon cancer cells via induction of amphiregulin. Cancer research. 2003; 63: 5218-23.

45. Greenhough A, Smartt HJ, Moore AE, Roberts HR, Williams AC, Paraskeva C, et al. The COX-2/PGE2 pathway: key roles in the hallmarks of cancer and adaptation to the tumour microenvironment. Carcinogenesis. 2009; 30: 377-86. doi:10.1093/carcin/bgp014.

46. Rundhaug JE, Simper MS, Surh I, Fischer SM. The role of the EP receptors for prostaglandin E2 in skin and skin cancer. Cancer metastasis reviews. 2011; 30: 465-80. doi:10.1007/s10555-011-9317-9.

47. Achiwa H, Yatabe Y, Hida T, Kuroishi T, Kozaki K, Nakamura S, et al. Prognostic significance of elevated cyclooxygenase 2 expression in primary, resected lung adenocarcinomas. Clinical cancer research : an official journal of the American Association for Cancer Research. 1999; 5 : 1001-5.

48. Shiff SJ, Rigas B. The role of cyclooxygenase inhibition in the antineoplastic effects of nonsteroidal antiinflammatory drugs (NSAIDs). The Journal of experimental medicine. 1999; 190: 445-50.

49. Waddell WR, Loughry RW. Sulindac for polyposis of the colon. Journal of surgical oncology. 1983; 24: 83-7.

50. Waddell WR, Ganser GF, Cerise EJ, Loughry RW. Sulindac for polyposis of the colon. American journal of surgery. 1989; 157: 175-9.

51. Smalley WE, DuBois RN. Colorectal cancer and nonsteroidal anti-inflammatory drugs. Advances in pharmacology. 1997; 39: 1-20.

52. Grosch S, Maier TJ, Schiffmann S, Geisslinger G. Cyclooxygenase-2 (COX-2)-independent anticarcinogenic effects of selective COX-2 inhibitors. Journal of the National Cancer Institute. 2006; 98: 736-47. doi:10.1093/jnci/dij206.

53. Tegeder I, Pfeilschifter J, Geisslinger G. Cyclooxygenase-independent actions of cyclooxygenase inhibitors. FASEB journal : official publication of the Federation of American Societies for Experimental Biology. 2001; 15: 2057-72. doi:10.1096/fj.01-0390rev.

54. Soh JW, Weinstein IB. Role of COX-independent targets of NSAIDs and related compounds in cancer prevention and treatment. Progress in experimental tumor research. 2003; 37: 261-85.

55. Jordan MA, Wilson L. Microtubules and actin filaments: dynamic targets for cancer chemotherapy. Current opinion in cell biology. 1998; 10: 123-30.

56. Subbaramaiah K, Hart JC, Norton L, Dannenberg AJ. Microtubule-interfering agents stimulate the transcription of cyclooxygenase-2. Evidence for involvement of ERK1/2 AND p38 mitogen-activated protein kinase pathways. The Journal of biological chemistry. 2000; 275: 14838-45.

57. Lee LF, Li G, Templeton DJ, Ting JP. Paclitaxel (Taxol)-induced gene expression and cell death are both mediated by the activation of c-Jun NH2-terminal kinase (JNK/SAPK). The Journal of biological chemistry. 1998; 273: 28253-60

58. Wang TH, Wang HS, Ichijo H, Giannakakou P, Foster JS, Fojo T, et al. Microtubule-interfering agents activate c-Jun N-terminal kinase/stress-activated protein kinase through both Ras and apoptosis signal-regulating kinase pathways. The Journal of biological chemistry. 1998; 273: 4928-36.

59. Dixon DA, Kaplan CD, McIntyre TM, Zimmerman GA, Prescott SM. Post-transcriptional control of cyclooxygenase-2 gene expression. The role of the 3'-untranslated region. The Journal of biological chemistry. 2000; 275: 11750-7.

60. Dixon DA, Tolley ND, King PH, Nabors LB, McIntyre TM, Zimmerman GA, et al. Altered expression of the mRNA stability factor HuR promotes cyclooxygenase-2 expression in colon cancer cells. The Journal of clinical investigation. 2001; 108: 1657-65. doi:10.1172/JCI12973.
61. Edelman MJ, Tan MT, Fidler MJ, Sanborn RE, Otterson G, Sequist LV, et al. Randomized, double-blind, placebo-controlled, multicenter phase II study of the efficacy and safety of apricoxib in combination with either docetaxel or pemetrexed in patients with biomarker-selected non-small-cell lung cancer. Journal of clinical oncology : official journal of the American Society of Clinical Oncology. 2015; 33: 189-94. doi:10.1200/JCO.2014.55.5789.

62. Aruajo AM, Mendez JC, Coelho AL, Sousa B, Barata F, Figueiredo A, et al. Phase II study of celecoxib with cisplatin plus etoposide in extensive-stage small cell lung cancer. Cancer investigation. 2009; 27: 391-6. doi:10.1080/07357900802232756.

63. Chen M, Yu L, Gu C, Zhong D, Wu S, Liu S. Celecoxib antagonizes the cytotoxic effect of cisplatin in human gastric cancer cells by decreasing intracellular cisplatin accumulation. Cancer letters. 2013; 329: 189-96. doi:10.1016/j.canlet.2012.10.030.

64. Yokouchi H, Kanazawa K. Revisiting the role of COX-2 inhibitor for non-small cell lung cancer. Translational lung cancer research. 2015; 4: 660-4. doi:10.3978/j.issn.2218-6751.2015.04.03.

65. Gitlitz BJ, Bernstein E, Santos ES, Otterson GA, Milne G, Syto M, et al. A randomized, placebo-controlled, multicenter, biomarker-selected, phase 2 study of apricoxib in combination with erlotinib in patients with advanced non-small-cell lung cancer. Journal of thoracic oncology : official publication of the International Association for the Study of Lung Cancer. 2014; 9: 577-82. doi:10.1097/JTO.0000000000000082.

66. Reckamp KL, Koczywas M, Cristea MC, Dowell JE, Wang HJ, Gardner BK, et al. Randomized phase 2 trial of erlotinib in combination with high-dose celecoxib or placebo in patients with advanced non-small cell lung cancer. Cancer. 2015; 121: 3298-306. doi:10.1002/cncr.29480.

67. Reckamp KL, Krysan K, Morrow JD, Milne GL, Newman RA, Tucker C, et al. A phase I trial to determine the optimal biological dose of celecoxib when combined with erlotinib in advanced non-small cell lung cancer. Clinical cancer research : an official journal of the American Association for Cancer $\quad$ Research. 2006; 12 : 3381-8. doi:10.1158/1078-0432.CCR-06-0112.

68. Reckamp K, Gitlitz B, Chen LC, Patel R, Milne G, Syto M, et al. Biomarker-based phase I dose-escalation, pharmacokinetic, and pharmacodynamic study of oral apricoxib in combination with erlotinib in advanced nonsmall cell lung cancer. Cancer. 2011; 117: 809-18. doi:10.1002/cncr.25473.

69. Agarwala A, Fisher W, Bruetman D, McClean J, Taber D, Titzer M, et al. Gefitinib plus celecoxib in chemotherapy-naive patients with stage IIIB/IV non-small cell lung cancer: a phase II study from the Hoosier Oncology Group. Journal of thoracic oncology : official publication of the International Association for the Study of Lung Cancer. 2008; 3: 374-9. doi:10.1097/JTO.0b013e3181693869.

70. Fidler MJ, Argiris A, Patel JD, Johnson DH, Sandler A, Villaflor VM, et al. The potential predictive value of cyclooxygenase-2 expression and increased risk of gastrointestinal hemorrhage in advanced non-small cell lung cancer patients treated with erlotinib and celecoxib. Clinical cancer research : an official journal of the American Association for Cancer Research. 2008; 14: 2088-94. doi:10.1158/1078-0432.CCR-07-4013.

71. Gadgeel SM, Ruckdeschel JC, Heath EI, Heilbrun LK, Venkatramanamoorthy R, Wozniak A. Phase II study of gefitinib, an epidermal growth factor receptor tyrosine kinase inhibitor (EGFR-TKI), and celecoxib, a cyclooxygenase-2 (COX-2) inhibitor, in patients with platinum refractory non-small cell lung cancer (NSCLC). Journal of thoracic oncology : official publication of the International Association for the Study of Lung Cancer. 2007; 2: 299-305. doi:10.1097/01.JTO.0000263712.61697.69.

72. O'Byrne KJ, Danson S, Dunlop D, Botwood N, Taguchi F, Carbone D, et al. Combination therapy with gefitinib and rofecoxib in patients with platinum-pretreated relapsed non small-cell lung cancer. Journal of clinical oncology : official journal of the American Society of Clinical Oncology. 2007; 25: 3266-73, doi:10.1200/JCO.2006.09.2791.

73. Veltman JD, Lambers ME, van Nimwegen M, Hendriks RW, Hoogsteden HC, Aerts JG, et al. COX-2 inhibition improves immunotherapy and is associated with decreased numbers of myeloid-derived suppressor cells in mesothelioma. Celecoxib influences MDSC function. BMC cancer. 2010; 10: 464. doi:10.1186/1471-2407-10-464.

74. Eberstal S, Sanden E, Fritzell S, Darabi A, Visse E, Siesjo P. Intratumoral COX-2 inhibition enhances GM-CSF immunotherapy against established mouse GL261 brain tumors. International journal of cancer. 2014; 134: 2748-53. doi:10.1002/ijc. 28607. 